\title{
ANALISIS PERLAKUAN AKUNTANSI PENDAPATAN PADA PT. BANK MALUKU AMBON
}

\author{
Mia Papilaya ${ }^{1}$, Ventje Ilat $^{2}$, Heince Wokas ${ }^{3}$ \\ 1,2,3 Jurusan Akuntansi, Fakultas Ekonomi dan Bisnis, Universitas Sam Ratulangi, Jl. Kampus Unsrat Bahu, \\ Manado, 95115, Indonesia \\ E-mail: mia.papilaya46@yahoo.com
}

\begin{abstract}
The bank is a financial institution which main function is to collect funds from the public, distributing funds to the community, and also provides services in the form of banking service. Each company in the preparation of financial statements is an important basis for determining the financial performance of companies which includes interest income. This study was conducted to see how the accounting treatment of income at PT. Bank Maluku, whether it has been implemented in accordance with PSAK No.31. This type research used qualitative data method. Source data used are primary data. The method of analysis done is descriptive method. The results showed in the accounting treatment of interest income at PT. Bank Maluku. Interest income is income earned from the investment of bank funds in productive asset. Accrued interest income (accrual basis), except for interest income from troubled assets. It can be seen that the accounting treatment of income at PT. Bank Maluku is in compliance with PSAK No.31.
\end{abstract}

Keywords : Treatment, Interest Income

\section{PENDAHULUAN}

Dalam menjalankan usaha saat ini sangat membutuhkan dana untuk pembangunan di segala bidang baik itu komunikasi, pendidikan, sarana transportasi serta yang lainnya. Dana yang dibutukan itu umumnya didapat dari lembaga keuangan yang disebut bank.

Bank merupakan lembaga keuangan yang fungsi utamanya adalah menghimpun dana dari masyarakat, menyalurkan dana kepada masyarakat, dan juga memberikan pelayanan dalam bentuk jasa-jasa perbankan (Ismail, 2014:2).

Untuk memenuhi kebutuhan dana yang diperlukan oleh pihak-pihak yang memerlukan dana bank haruslah dikelolah secara efektif dan efisien sehingga dapat mencapai tujuan yang diinginkan. Hal itu dapat diperoleh bila ditunjang dengan informasi yang tepat, lengkap, up to date, dapat dipercaya, mudah dimengerti, serta dapat dianalisa. Laporan perhitungan laba rugi, sebagai sumber informasi merupakan salah satu laporan keuangan, yang menjadi pusat perhatian baik pihak ekstern maupun pihak intern. Laporan perhitungan laba rugi merupakan suatu laporan atas dasar mana sukses yang dicari dan kegagalan yang diderita suatu bank di dalam menjalankan usahanya dalam jangka waktu (periode) tertentu.

Dalam PSAK No.1 (2012) "Tujuan umum laporan keuangan adalah memberikan informasi mengenai posisi keuangan, kinerja keuangan, dan arus kas entitas yang bermanfaat bagi sebagian besar kalangan pengguna laporan dalam pembuatan keputusan ekonomi serta menunjukan hasil pertanggungjawaban manajemen atas penggunaan sumber daya yang dipercayakan kepada mereka."

Pendapatan merupakan salah satu unsur yang mempengaruhi laporan laba rugi. Pengakuan dan pengukuran yang layak terhadap pendapatan begitu penting karena berpengaruh dalam pengukuran dan pelaporan laba. Pada prinsipnya penentuan pendapatan harus memenuhi kebutuhan akan penyusunan berkala/periode yang tepat. Kesalahan penyajian 
mengenai pendapatan bisa terjadi karena ketidaktepatan dalam pengakuan dan pengukuran metode yang digunakan, ketidaktepatan prosedur cut off/pisah batas, serta praktek akuntansi yang berlaku di bank. Akibatnya pelaporan pendapatan bisa overstatement/understatement yang pada akhirnya informasi pendapatan yang disajikan dapat menyesatkan pemakaiannya. Untuk itu diperlukan prinsip pengakuan pendapatan yang mempertimbangkan adanya penerapan sistem, metode dan praktek akuntansi yang sesuai dengan prinsip akuntansi yang berlaku dalam menghitung atau mengakui pendapatan, sehingga mampu memberikan informasi yang handal dan menggambarkan posisi keuangan yang sebenarnya.

PT. Bank Maluku merupakan salah satu bank yang menjalankan fungsinya sebagai bank umum dengan berbagai sarana, kemudahan dan pengalaman yang dimiliki selama ini. Bank Maluku masih dipercaya dan selalu siap menampung dan mengelola keuangan daerah maupun dana alokasi umum dan dana bantuan lainnya serta akan berperan dan memberikan kontribusi yang lebih besar bagi pembangunan ekonomi daerah Maluku.

Pendapatan bersih tahun berjalan pada PT. Bank Maluku tahun 2015 sebesar Rp.188.277.000, hasil tersebut didapati oleh pendapatan bunga yaitu sebesar Rp.713.645.000. Dari pendapatan tersebut dapat dilihat bahwa pentingnya perlakuan akuntansi pendapatan dalam hal penyajiannya laporan keuangan yang wajar dan dapat dipertanggungjawabkan, penulis tertarik untuk mengadakan observasi langsung terhadap penerapan akuntansi pendapatan yang diatur dalam PSAK No.31 tentang Akuntansi Perbankan dan sekaligus dapat memberikan penilaian tentang proses penyusunan dan penyajian laporan keuangan itu apakah telah dilaksanakan sesuai dengan SAK.

\section{TINJAUAN PUSTAKA}

\subsection{Akuntansi}

Akuntansi merupakan seni dalam mencatat, menggolongkan, dan mengikhtisarkan semua transaksi-transaksi yang terkait dengan keuangan yang telah terjadi dengan suatu cara yang bermakna dan dalam satuan uang (Ismail, 2014).

\subsection{Tahap-Tahap Akuntansi}

Menurut Hery (2014:2) menyatakan bahwa tahapan-tahapan dalam siklus akuntansi dapat di urutkan sebagai berikut:

1. Mula-mula dokumen pendukung transaksi dianalisis dan informasi yang terkandung dalam dokumen tersebut dicatat dalam jurnal.

2. Lalu data akuntansi yang ada dalam jurnal di posting ke buku besar.

3. Seluruh saldo akhir yang terdapat pada masing-masing buku besar akun "didaftar" (dipindahkan) ke neraca saldo untuk membuktikan kecocokan antara keseluruhan nilai akun yang bersaldo normal debet dengan keseluruhan nilai akun yang bersaldo normal kredit.

4. Menganalisis data penyesuaian dan membuat ayat jurnal penyesuaian.

5. Memposting data jurnal penyesuaian ke masing-masing buku besar akun yang terkait.

6. Dengan menggunakan pilihan (optional) bantuan neraca lajur sebagai kertas kerja (work sheet), neraca saldo setelah penyesuaian (adjusted trial balance) dan laporan keuangan disiapkan.

7. Membuat ayat jurnal penutup (closing entries).

8. Memposting data jurnal penutup ke masing-masing buku besar akun yang terkait.

9. Menyiapkan neraca saldo setelah penutupan (post-closing trial balance).

10. Membuat ayat jurnal pembalik (reversing entries).

\subsection{Kerangka Konseptual Akuntansi}

Menurut Taswan (2013), menjelaskan bahwa "Kerangka konseptual akuntansi adalah suatu sistem pertalian yang erat (koheren) dari tujuan dan konsep-konsep dasar yang saling berhubungan dan saling mengarahkan terciptanya prinsip-prinsip yang konsisten serta 
menggambarkan sifat, fungsi dan keterbatasan akuntansi beserta laporan keuangan. Sebagai konsep, tentu akan memberikan manfaat bagi perkembangan akuntansi atau sebaliknya perkembangan akuntansi yang memberikan manfaat kepada konsep dasar akuntansi. Oleh karena itu dalam menghadapi persoalan akuntansi hendaknya dapat dikembalikan pada konsep dasarnya."

Selanjutnya kerangka konseptual akuntansi mempunyai manfaat sebagai berikut:

a. Akan dapat dirumuskan prinsip-prinsip akuntansi yang dapat menjadi acuan bagi para pemakai informasi akuntansi.

b. Akan dihasilkan tujuan dan dasar-dasar praktek akuntansi dan pelaporan keuangan.

c. Akan memberikan pedoman untuk memilih alternatif yang mencerminkan posisi keuangan dan hasil operasi dengan cara yang paling akurat dalam lingkungan tertentu.

\subsection{Sistem Akuntansi Perbankan}

Menurut Taswan (2013) sebuah sistem Akuntansi Perbankan dibangun untuk mencapai sasaran tertentu, yaitu :

a. Sebagai Sistem Informasi Manajemen.

b. Sebagai Sistem Penentuan Biaya.

c. Sebagai Sistem Pengawasan.

d. Sebagai Sistem Laporan kepada Penguasa Moneter.

\subsection{Pengertian Perlakuan Akuntansi}

Menurut Suwardjono (2010), menjelaskan bahwa perlakuan akuntansi dilandasi oleh standar akuntansi, dan secara garis besar ada 4 hal pokok yang diatur dalam standar akuntansi, yaitu :

1. Pengukuran (measurement) atau penilaian (valuation).

2. Definisi elemen dan pos laporan keuangan.

3. Pengakuan (recognition).

4. Pengungkapan/penyajian (disclosure/presentation).

\subsection{Laporan Keuangan}

Menurut Sutrisno (2012) Laporan keuangan adalah beberapa lembar kertas yang bertulisan angka-angka, tetapi sangat penting juga untuk menentukan aktiva ril dibalik angkaangka tersebut. Laporan keuangan merupakan hasil akhir dari akuntansi yang meliputi dua laporan yakni neraca dan rugi-laba. Laporan keuangan disusun dengan maksud untuk menyediakan suatu perusahaan kepada pihak-pihak yang berkepentingan sebagai bahan pertimbangan didalam mengambil keputusan. Pihak-pihak yang berkeptingan tersebut antara lain adalah manajemen, pemilik, kreditor, investor, dan pemerintah.

Laporan keuangan bank merupakan bentuk pertanggungjawaban manajemen terhadap pihak-pihak yang berkepentingan dengan kinerja bank yang dicapai selama periode tertentu. Tujuan laporan keuangan bank adalah untuk memberikan informasi tentang posisi keuangan, kinerja, perubahan ekuitas, arus kas, dan informasi lainnya yang bermanfaat bagi pengguna laporan keuangan dalam rangka membuat keputusan ekonomi serta menunjukan pertanggungjawaban manajemen atas penggunaan sumber daya yang dipercayakan kepada mereka (PAPI 2001) (Ismail, 2014).

Samryn (2014) menyatakan bahwa: "Secara umum laporan keuangan meliputi ikhtisarikhtisar yang menggambarkan posisi keuangan, hasil usaha, dan arus kas serta perubahan ekuitas sebuah organisasi dalam satu periode waktu tertentu. Tiap ikhtisar tersebut dibuat dalam satu format sendiri secara terpisah."

Laporan keuangan umumnya terdiri dari hal-hal berikut:

1. Neraca.

2. Laporan laba rugi.

3. Laporan arus kas.

4. Laporan perubahan modal. 
5. Catatan atas laporan keuangan.

\subsection{Tujuan Laporan Keuangan}

Menurut Kasmir (2016:10) tujuan laporan keuangan yaitu:

1. Memberikan informasi tentang jenis dan jumlah aktiva (harta) yang dimiliki perusahaan pada saat ini.

2. Memberikan informasi tentang jenis dan jumlah kewajiban dan modal yang dimiliki perusahaan pada saat ini.

3. Memberikan informasi tentang jenis dan jumlah pendapatan yang diperoleh pada suatu periode tertentu.

4. Memberikan informasi tentang jumlah biaya dan jenis biaya yang dikeluarkan perusahaan dalam suatu periode tertentu.

5. Memberikan informasi tentang perubahan-perubahan yang terjadi terhadap aktiva, pasiva, dan modal perusahaan.

6. Memberikan informasi tentang kinerja manajemen perusahaan dalam suatu periode.

7. Memberikan informasi tentang catatan-catatan atas laporan keuangan.

\subsection{Pendapatan}

8. Informasi keuangan lainnya.

Pendapatan dinyatakan sebagai : Arus masuk atau penyelesaian (atau kombinasi keduanya) dari pengiriman atau produksi barang, memberikan jasa atau melakukan aktivitas lain yang merupakan aktivitas utama atau aktivitas centra yang sedang berlangsung (Skousen, Stice dan Stice, 2010:161).

\subsection{Pengakuan Pendapatan}

Ikatan Akuntansi Indonesia dalam Pernyataan Standar Akuntansi Keuangan (PSAK) Nomor 23 (2010) menyatakan bahwa pendapatan diakui bila besar kemungkinan manfaat ekonomi masa depan akan mengalir ke perusahaan. Pernyataan Standar Akuntansi Keuangan No. 23 menyatakan bahwa penjualan jasa dapat diakui dengan persentase penyelesaian bila memenuhi kondisi berikut:

1. Jumlah pendapatan dapat diukur dengan andal.

2. Kemungkinan besar manfaat ekonomi sehubungan dengan transaksi tersebut akan mengalir ke entitas.

3. Tingkat penyelesaian dari suatu transaksi pada akhir periode pelaporan dapat diukur secara andal.

4. Biaya yang timbul untuk transaksi dan biaya untuk menyelesaikan transaksi tersebut dapat diukur secara andal.

\subsection{Kriteria Pengakuan Pendapatan}

Secara umum menurut FASB (Financial Accounting Standards Board) sebagaimana dikutip oleh Suwardjono (2010) mengajukan dua kriteria pengakuan pendapatan:

a. Pendapatan baru dapat diakui bilamana jumlah rupiah pendapatan telah terealisasi (realized atau realizable).

b. Pendapatan baru dapat diakui bilamana pendapatan tersebut sudah terhimpun atau terbentuk (earned). Untuk memperoleh pendapatan perusahaan harus melakukan kegiatan memproduksi barang atau jasa yang menjadi sumber pendapatan.

\subsection{Pengukuran Pendapatan}

Sehubungan dengan pengakuan pendapatan salah satu kriteria bahwa pendapatan itu dapat diakui adalah measurability, dimana pendapatan itu dapat ditentukan besarnya dengan wajar agar didalam laporan keuangan itu tidak tercermin pendapatan yang terlalu tinggi (over stated) dan terlalu rendah (under stated). Harahap (2011: 96) menyatakan bahwa pengukuran adalah proses penetapan jumlah uang untuk mengakui dan memasukkan setiap unsur laporan keuangan dalam neraca atau laporan laba rugi. 


\subsection{Akuntansi Pendapatan dan Beban}

Menurut Ikatan Akuntan Indonesia dalam Pernyataan Standar Akuntansi Keuangan No. 31 (Revisi 2009) standar akuntansi perbankan mengatur tentang pengakuan pendapatan dan beban bunga adalah sebagai berikut :

a. Pendapatan dan beban bunga diakui secara akrual (accrual basis) kecuali pendapatan bunga dari kredit dan aktiva produktif lainnya yang nonperforming. Pendapatan dari aktiva yang non performing hanya boleh diakui apabila pendapatan tersebut benar-benar telah diterima. Pendapatan dari aktiva produktif non performing yang belum diterima tidak dapat diakui sebagai pendapatan dalam periode laporan dan harus dilaporkan dalam laporan komitmen dan kontinjensi.

b. Pendapatan bunga terdiri atas pendapatan bunga dan pendapatan lain yang berkaitan langsung dengan pemberian kredit seperti provisi dan komisi.

c. Beban bunga terdiri atas beban dan beban lain yang dikeluarkan secara langsung dalam rangka penghimpunan dana tersebut seperti hadiah, premi atau diskonto dari kontrak berjangka dalam rangka pendanaan (funding).

\subsection{Pengakuan Pendapatan dan Beban Atas Komisi dan Provisi}

Menurut Ikatan Akuntan Indonesia dalam Pernyataan Standar Akuntansi Keuangan No.

31 (Revisi 2009) akuntansi perbankan tentang pendapatan dan beban atas komisi dan provisi adalah sebagai berikut:

a. Komisi dan provisi yang berkaitan langsung dengan kegiatan perkreditan diperlakukan sebagai pendapatan atau beban yang ditangguhkan akan diamortisasi secara sistematis selama jangka waktu komitmen kredit. Apabila komitmen tersebut diselesaikan sebelum jangka waktunya maka sisa komis idan provisi diakui sebagai pendapatan atau beban pada saat penyelesaian komitmen tersebut.

b. Komisi dan provisi yang tidak berkaitan langsung dengan kegiatan perkreditan namun terkait dengan jangka waktu diperlakukan sebagai pendapatan atau beban yang ditangguhkan dan diamortisasi secara sistematis selama jangka waktu tertentu.

c. Komisi dan provisi yang tidak berkaitan dengan kegiatan perkreditan dan jangka waktu, diakui sebagai pendapatan atau beban pada saat terjadinya transaksi.

\section{METODE PENELITIAN}

\subsection{Jenis Penelitian}

Jenis penelitian yang digunakan adalah penelitian kualitatif. Data yang dibutuhkan dalam penelitian ini adalah gambaran dari analisis perlakuan akuntansi pendapatan pada PT. Bank Maluku Ambon.

\subsection{Sumber Penelitian}

Penelitian ini menggunakan data primer, data yang secara langsung dikumpulkan oleh penulis dari sumber aslinya yang berupa wawancara dan laporan keuangan.

\subsection{Tempat dan Waktu Penelitian}

Penelitian ini dilakukanpada PT. Bank Maluku Ambon. Waktu yang akan digunakan untuk melakukan penelitian ini adalah pada bulan Maret 2017

\subsection{Metode Analisis Data}

Untuk menganalisa data dalam penelitian ini maka akan digunakan metode analisa deskriptif. Metode deskriptif dipakai untuk membandingkan perlakuan akuntansi terhadap pendapatan yang diterapkan oleh PT. Bank Maluku dengan PSAK No. 31. Data yang terkumpul diamati dan diuji untuk selanjutnya ditelusuri kembali untuk mendapatkan hal-hal 
yang merupakan sebab yang berhubungan dengan pengertian atau maknanya. Lebih lanjut dibuat suatu komparasi dan analisis dengan membandingkan kesesuaiannya terhadap suatu alat ukur.

\subsection{Teknik Pengumpulan Data}

1. Mengetahui dan mempelajari gambaran umum PT. Bank Maluku serta mengetahui permasalahan yang ada, dalam hal ini perlakuan akuntansi terhadap pendapatan pada PT. Bank Maluku yang dilakukan dengan wawancara dengan pihak bank.

2. Mempelajari permasalahan yang ada dalam hal ini melakukan pengumpulan data melalui literatur yang ada untuk dijadikan landasan teori dalam menilai permasalahan tersebut.

3. Penilaian terhadap data yang diperoleh berupa perlakuan akuntansi yang diterapkan terhadap pendapatan dihubungkan dengan aktivitas usaha perbankan pada PT. Bank Maluku.

4. Menarik kesimpulan serta saran-saran terhadap hasil analisis perlakuan akuntansi atas pendapatan PT. Bank Maluku.

\section{HASIL ANALISIS DAN PEMBAHASAN}

\subsection{Hasil analisis}
1. Perlakuan Akuntansi Pendapatan Bunga

Pendapatan bunga adalah pendapatan yang diperoleh dari penanaman dana bank pada aktiva produktif. Pendapatan bunga diakui secara akrual (accrual basis), kecuali pendapatan bunga dari aktiva produktif nonperforming. Pendapatan dari aktiva yang nonperforming hanya boleh di akui apabila pendapatan tersebut benar-benar telah diterima (cash basis). Yang dimaksud dengan nonperforming adalah suatu keadaan yang menunjukkan bahwa aktiva produktif digolongkan kurang baik. Kredit nonperforming terdiri atas kredit yang digolongkan sebagai kredit kurang lancar, diragukan, dan macet. Seluruh penerimaan yang berhubungan dengan kredit diragukan dan macet diakui terlebih dahulu sebagai pengurang pokok kredit.

a. Pendapatan Bunga pada PT. Bank Maluku pada tahun 2015 terdiri dari:

1. Pendapatan bunga dari kredit yang diberikan.

Kas Rp.612.242.000

$$
\text { Pendapatan Bunga Kredit Rp.612.242.000 }
$$

2. Pendapatan Pada BI dan Bank Lain.

$$
\begin{aligned}
& \text { Ras } 85.883 .000 \\
& \text { Pendapatan Bunga pada BI dan Bank Lain } \quad \text { Rp.85.883.000 }
\end{aligned}
$$

3. Pendapatan Bunga dari Efek-efek.

Kas

$$
\text { Rp.11.136.000 }
$$

$$
\text { Pendapatan Bunga dari sikuritas Rp.11.136.000 }
$$

4. Pendapatan Bunga dari Giro pada Bank Lain dan BI.

Kas Rp.2.368.000

Pendapatan Giro Bank Lain dan BI Rp.2.368.000

b. Beban Bunga pada PT.Bank Maluku pada tahun 2015, yaitu:

Beban Bunga

Rp.221.416.000

$$
\text { Hutang Bunga Rp.221.416.000 }
$$

\section{Perlakuan Akuntansi Pendapatan Provisi dan Komisi}

Komisi merupakan pendapatan bank yang sedang digiatkan belakangan. Komisi ini merupakan beban yang diperhitungkan kepada para nasabah bank yang mempergunakan jasa bank. Komisi juga lazimnya dibukukan langsung sebagai pendapatan pada saat bank menjual 
jasa kepada nasabahnya, sedangkan provisi merupakan sumber pendapatan bank yang akan diterima dan diakui sebagai pendapatan pada saat kredit disetujui oleh bank. Biasanya provisi kredit langsung dibayarkan oleh nasabah yang bersangkutan.

Perlakuan akuntansi terhadap komisi dan provisi adalah sebagai berikut:

1. Komisi dan provisi yang berkaitan langsung dengan kegiatan perkreditan diperlakukan sebagai pendapatan atau beban yang ditangguhkan dan diamortisasi secara sistematis selama jangka waktu komitmen kredit. Apabila komitmen tersebut diselesaikan sebelum jangka waktunya berakhir maka sisa komisi dan provisi harus diakui sebagai pendapatan atau beban pada saat penyelesaian komitmen tersebut. Pendapatan komisi dan provisi kredit disajikan sebagai bagian dari pendapatan bunga pada perhitungan laba rugi, sedangkan beban komisi dan provisi kredit disajikan sebagai bagian dari beban bunga.

2. Komisi dan provisi yang tidak berkaitan langsung dengan kegiatan perkreditan namun terkait dengan jangka waktu yang tidak diperlakukan sebagai pendapatan atau beban yang ditangguhkan dan diamortisasi secara sistematis selama jangka waktunya. Pendapatan atau beban komisi dan provisi tersebut disajikan sebagai bagian dari pendapatan dan beban operasi lainnya pada perhitungan laba rugi.

3. Komisi dan provisi yang tidak berkaitan dengan kegiatan perkreditan dan jangka waktu, diakui sebagai pendapatan atau beban pada saat terjadinya transaksi. Pendapatan atau beban komisi dan provisi tersebut disajikan sebagai bagian dari pendapatan dan beban operasional lainnya pada perhitungan laba rugi.

Jurnal provisi/komisi kredit yang dibuat tahun 2015 sebagai berikut :

Kas

Rp.6.332.000

$$
\text { Provisi kredit diterima dimuka Rp.6.332.000 }
$$

\subsection{Pembahasan}

1. Analisis Perlakuan Akuntansi Pendapatan Bunga

Pengakuan pendapatan dan beban bunga merupakan hal yang sangat fundamental dan menjadi dasar utama untuk menentukan profitabilitas bank. Kegiatan utama bank adalah menghimpun dana yang pada umumnya berbunga (interest bearing) dan menanamkan dalam aktiva produktif. Perbedaan waktu antara diterimanya pendapatan dan terjadinya beban atas penggunaan sumber daya untuk menghasilkan pendapatan dalam beban bank diperhatikan karakteristik usaha bank tersebut. Berdasarkan hasil penelitian diketahui bahwa pendapatan bunga Bank Maluku terdiri dari : Pendapatan bunga dari kredit yang diberikan, Pendapatan bunga dari BI dan Bank Lain, Pendapatan bunga dari Efek-efek, Pendapatan bunga dari Giro pada Bank Lain dan BI, dan Beban bunga. Pengakuan pendapatan bunga di Bank Maluku sudah sesuai dengan PSAK No. 31 tentang akuntansi perbankan. Menurut PSAK No. 31, pendapatan bunga diakui secara akrual kecuali pendapatan bunga dari kredit dan aktiva lainnya yang "nonperforming". Pendapatan dari aktiva yang nonperforming hanya boleh diakui apabila pendapatan tersebut benar-benar telah diterima. Pendapatan dari aktiva produktif nonperforming yang belum diterima tidak dapat diakui sebagai pendapatan dalam periode laporan dan harus dilaporkan dalam laporan komitmen dan kontinjensi.

2. Analisis Perlakuan Akuntansi Pendapatan Provisi dan Komisi

Pendapatan selain bunga dan beban selain bunga yang berkaitan dengan jangka waktu diakui selama jangka waktu tersebut. Contoh pendapatan selain bunga dan beban selain bunga yang berkaitan dengan jangka waktu ialah komisi dan provisi atau komitmen kredit diselesaikan sebelum jangka waktunya, maka sisa pendapatan dan beban diakui pada saat penyelesaian kredit atau komitmen tersebut. Pengakuan pendapatan provisi dan komisi pada PT. Bank Maluku telah sesuai dengan standar akuntansi keuangan, khususnya PSAK No. 31 tentang 
akuntansi perbankan. Dimana pengakuan pendapatan provisi dan komisi yang berkaitan langsung dengan perkreditan diperlakukan sebagai pendapatan yang ditangguhkan dan diamortisasi selama jangka waktu komitmen kredit. Begitu juga dengan pengakuan pendaptan provisi dan komisi yang tidak berkaitan langsung dengan perkreditan, namun terkait dengan jangka waktu diperlakukan sama dengan pendapatan provisi dan komisi yang berkaitan langsung dengan perkreditan. Sedangkan untuk pendapatan provisi dan komisi yang tidak terkait dengan perkreditan dan jangka waktu, diakui sebagai pendapatan pada saat terjadinya transaksi.

\section{KESIMPULAN DAN SARAN}

\subsection{Kesimpulan}

Pendapatan bunga pada PT.Bank Maluku terdiri dari : Pendapatan bunga dari kredit yang diberikan, Pendapatan bunga dari BI dan Bank Lain, Pendapatan bunga dari Efek-efek, Pendapatan bunga dari Giro pada Bank Lain dan BI, dan Beban bunga. Perlakuan akuntansi pendapatan bunga untuk aktiva produktif yang digolongkan performing diakui secara akrual, sedangkan untuk aktiva produktif yang digolongkan nonperforming hanya dapat diakui sebagai pendapatan bila telah diterima secara tunai. Pengakuan pendapatan bunga di Bank Maluku sudah sesuai dengan PSAK No. 31 tentang Akuntansi Perbankan.

1. Pengakuan pendapatan komisi dan provisi pada Bank Maluku telah sesuai dengan Standar Akuntansi Keuangan, khususnya PSAK No. 31 tentang Akuntansi Perbankan. Dimana pengakuan pendapatan komisi dan provisi yang berkaitan dengan perkreditan diperlakukan sebagai pendapatan yang ditangguhkan dan diamortisasi secara sistematis selama jangka waktu komitmen kredit. Begitu juga dengan pendapatan komisi dan provisi yang tidak berkaitan dengan perkreditan namun terkait dengan jangka waktu diperlakukan sama dengan komisi dan provisi yang berkaitan dengan perkreditan.

2. Pengakuan untuk pendapatan komisi dan provisi yang tidak berkaitan dengan kegiatan perkreditan dan jangka waktu diakui sebagai pendapatan pada saat terjadinya transaksi, begitu juga dengan pendapatan lainnya telah sesuai dengan Pernyataan Standar Akuntansi Keuangan No. 31 tentang Akuntansi Perbankan.

\subsection{Saran}

Saran yang diberikan adalah karena PT. Bank Maluku sering mendapat penghargaan atas berbagai prestasi di dunia perbankan, untuk itu PT. Bank Maluku harus mempertahankan apa yang telah didapatnya, dan peningkatan profesionalisme jajaran PT. Bank Maluku merupakan suatu keharusan untuk mencapai prestasi yang lebih baik dan diharapkan kebijakan pemerintah di bidang perbankan dapat memberikan iklim kondusif bagi perkembangan perbankan.

\section{DAFTAR PUSTAKA}

Harahap. 2011. Teori Akuntansi. Edisi Revisi 2011. Rajawali Pers. Jakarta.

Hery. 2014. Akuntansi Dasar. PT. Grasindo, anggota Ikapi. Jakarta.

Ismail. 2014. Akuntansi Bank. Edisi Revisi. PT. Adhitya Andrebina Agung. Jakarta.

Kasmir. 2016. Analisis Laporan Keuangan. Cetakan Kelima. Jakarta.

Samryn. 2014. Pengantar Akuntansi. Salemba Empat. Jakarta.

Sujarweni. 2016. Sistem Akuntansi. PT. Pustaka Baru. Yogyakarta.

Sutrisno. 2012. Keuangan Teori Dan Konsep. Yogyakarta.

Suwardjono. 2010. Teori Akuntansi. Edisi Ketiga. Yogyakarta.

Taswan. 2013. Akuntansi Perbankan Transaksi dalam Valuta Rupiah. Edisi Ketiga. Semarang. 